\title{
A new quantitative approach to identify reworking in Eocene to Miocene pollen records from offshore Antarctica using red fluorescence and digital imaging
}

\author{
Stephanie L. Strother ${ }^{1}$, Ulrich Salzmann ${ }^{1}$, Francesca Sangiorgi ${ }^{2}$, Peter K. Bijl ${ }^{2}$, Jörg Pross ${ }^{3}$, Carlota Escutia ${ }^{4}$, \\ Ariadna Salabarnada ${ }^{4}$, Matthew J. Pound ${ }^{1}$, Jochen Voss ${ }^{5}$, and John Woodward ${ }^{1}$ \\ ${ }^{1}$ Department of Geography, Faculty of Engineering and Environment, Northumbria University, Ellison Building, \\ Newcastle upon Tyne, NE1 8ST, UK \\ ${ }^{2}$ Marine Palynology and Paleoceanography, Department of Earth Sciences, Faculty of Geosciences, Laboratory of \\ Palaeobotany and Palynology, Utrecht University, Heidelberglaan 2, 3584CS Utrecht, the Netherlands \\ ${ }^{3}$ Paleoenvironmental Dynamics Group, Institute of Earth Sciences, Heidelberg University, Im Neuenheimer Feld 234, \\ 69120 Heidelberg, Germany \\ ${ }^{4}$ Instituto Andaluz de Ciencias de la Tierra, CSIC-Universidad de Granada, Granada, Spain \\ ${ }^{5}$ School of Mathematics, University of Leeds, Leeds LS2 9JT, UK
}

Correspondence to: Stephanie L. Strother (slstrother2@gmail.com) and Ulrich Salzmann (ulrich.salzmann@ northumbria.ac.uk)

Received: 15 September 2016 - Discussion started: 24 October 2016

Revised: 16 March 2017 - Accepted: 30 March 2017 - Published: 24 April 2017

\begin{abstract}
Antarctic palaeoclimate evolution and vegetation history after the formation of a continent-scale cryosphere at the Eocene-Oligocene boundary, 33.9 million years ago, has remained a matter of controversy. In particular, the reconstruction of terrestrial climate and vegetation has been strongly hampered by uncertainties in unambiguously identifying non-reworked as opposed to reworked sporomorphs that have been transported into Antarctic marine sedimentary records by waxing and waning ice sheets. Whereas reworked sporomorph grains over longer non-successive geological timescales are easily identifiable within younger sporomorph assemblages (e.g. Permian sporomorphs in Pliocene sediments), distinguishing non-reworked from reworked material in palynological assemblages over successive geological time periods (e.g. Eocene sporomorphs in Oligocene sediments) has remained problematic. This study presents a new quantitative approach to identifying non-reworked pollen assemblages in marine sediment cores from circum-Antarctic waters. We measured the fluorescence colour signature, including red, green, and blue fluorescence; brightness; intensity; and saturation values of selected pollen and spore taxa from Eocene, Oligocene, and Miocene sediments from the
\end{abstract}

Wilkes Land margin Site U1356 (East Antarctica) recovered during Integrated Ocean Drilling Program (IODP) Expedition 318. Our study identified statistically significant differences in red-fluorescence values of non-reworked sporomorph taxa against age. We conclude that red fluorescence is a reliable parameter for identifying the presence of nonreworked pollen and spores in Antarctic marine sediment records from the circum-Antarctic realm that are influenced by glaciation and extensive reworking. Our study provides a new tool to accurately reconstruct Cenozoic terrestrial climate change on Antarctica using fossil pollen and spores.

\section{Introduction}

Antarctica plays a key role in understanding past and future global climate change due to the impact its large ice sheets exert on sea level as well as on oceanic and atmospheric circulation. Throughout the last 65 million years, the Antarctic continent has undergone a drastic change from a greenhouse environment in the early Paleogene towards an icehouse world in the late Paleogene and Neogene (e.g. Askin 
and Raine, 2000; Prebble et al., 2006; Anderson et al., 2011; Pross et al., 2012; Bijl et al., 2013; Passchier et al., 2013). The analysis of fossil pollen and spores is one of the most important tools for reconstructing and quantifying past vegetation and terrestrial climate change. For Antarctica the lack of long and well-dated sediment records puts considerable constraints on a detailed spatial and temporal reconstruction of terrestrial environmental change. Macro- and microfossil evidence for vegetation cover from continental sections of Antarctica is often difficult to date and in general sparse due to past and present ice cover (e.g. Birkenmajer and Zastawniak, 1989; Pole et al., 2000; Lewis et al., 2008; Warny et al., 2016). Therefore, most reconstructions of climate and vegetation on the Antarctic continent are based on palynological records from marine, circum-Antarctic sediment cores. However, the waxing and waning of Antarctic ice sheets throughout the Oligocene and Miocene caused reworking of terrestrial material into marine sediments, ultimately leading to a combination of non-reworked and reworked palynomorphs in palaeo-records that are difficult to differentiate, especially over short geological timescales (e.g. Askin and Raine, 2000; Raine and Askin, 2001; Prebble et al., 2006; Salzmann et al., 2011; Griener et al., 2015).

The unambiguous identification of reworked palynomorphs in palaeo-records is essential for establishing reliable climate and vegetation reconstructions for the Antarctic continent. However, a quantitative approach to differentiating non-reworked from reworked pollen assemblages over relative short geological timescales (e.g. Oligocene to Miocene) has not yet been established. Previous palynological studies in Antarctica have identified reworked Cenozoic sporomorphs using the thermal alteration of grains (e.g. Askin and Raine, 2000; Raine and Askin, 2001; Prebble et al., 2006; Griener et al., 2015; Warny et al., 2016). This approach only takes into account reworked pollen grains that have been exposed to significantly different taphonomic conditions than the non-reworked sporomorphs. However, submarine reworking of shelf material can only have small impacts on preservation quality, hampering the unambiguous identification of reworked palynomorphs using light microscopy (e.g. Salzmann et al., 2011).

Subjective fluorescence microscopy has been applied in Antarctic palynology to help remedy the issue of reworking. Raine (1998) and Salzmann et al. (2011) used autofluorescence to identify reworked Permian and Mesozoic sporomorphs within Cenozoic sediments from the Cape Roberts cores from the Ross Sea and James Ross Island, Antarctica. Qualitative attempts to separate reworked and non-reworked sporomorphs based on their fluorescence colours through geological time have been shown to work (Phillips, 1972; Bujak and Davies, 1982). However, these methods are highly subjective, being dependent upon the observer, and are difficult to reproduce.

By using fluorescence microscopy, this study aims to develop a new systematic and quantitative approach to identi- fying non-reworked pollen and spore assemblages in marine sediments from Antarctica. We measured the fluorescence signature, including red, green, and blue fluorescence colour (RGB); brightness; intensity; and saturation of the most common pollen and spore taxa under ultraviolet (UV) light in Eocene, Oligocene, and Miocene sediments. All samples were taken from the Wilkes Land margin sediment record at IODP Site U1356 (Fig. 1) and cover the early Eocene through the mid-Miocene, with two hiatuses from the mid-Eocene to the early Oligocene $(\sim 47-33.6 \mathrm{Myr})$ and from the late Oligocene to early Miocene ( $23.12-16.7 \mathrm{Myr})$ (Escutia et al., 2011; Tauxe et al., 2012). This provides us with four time intervals, all yielding abundant sporomorphs (Escutia et al., 2011; Pross et al., 2012; Contreras et al., 2013; Sangiorgi et al., 2017) in which we hypothesise different fluorescence behaviour. The Cenozoic sediment record of Site U1356 provides a unique opportunity to compare the fluorescence of the same pollen taxa through the Eocene to Miocene, i.e. before and during the impact of large-scale glaciation. The aim of our study is to provide a simple quantitative approach to identifying the presence of non-reworked palynomorphs in a given sediment layer that can be used to reliably reconstruct past vegetation and climate for the time interval during which the sediment was deposited.

\section{Conceptual model for identifying non-reworked palynomorphs in Antarctic sediments}

Various factors such as burial depth and geological age contribute to the fluorescence of sporomorphs. These factors reflect the ultimate determining factor of fluorescence alteration, which is heat flow and the length of time the sporomorphs are exposed to this heat (Waterhouse, 1998). The fluorescence signal from fossil pollen and spores comes from the sporopollenin in the exine, which contains heteroatomic compounds (Yeloff and Hunt, 2005). Over geological timescales pollen and spores in sediments are subjected to elevated temperatures and pressures after burial, and the less-resistant compounds of the sporopollenin shift to the red end of the colour spectrum and ultimately towards no fluorescence (Van Gijzel, 1967; Bujak and Davies, 1982; Yeloff and Hunt, 2005). This suggests that the colour of fluorescence changes with burial time: sporomorphs from older sediments (Cretaceous and older) show little to no fluorescence, and pollen and spores from older epochs of the Cenozoic (Paleocene, Eocene, and Oligocene) show fluorescence predominantly on the red end of the spectrum, with additional fluorescence colour (orange, yellow, blue, and green) variations, including red fluorescence, continuing through to modern times (Bujak and Davies, 1982). Critically, the process of fluorescence loss is irreversible, meaning that fluorescence cannot be re-gained by the sporomorphs at any time.

The predictable change in colour and intensity of fluorescence described above in relation to burial time and depth, 


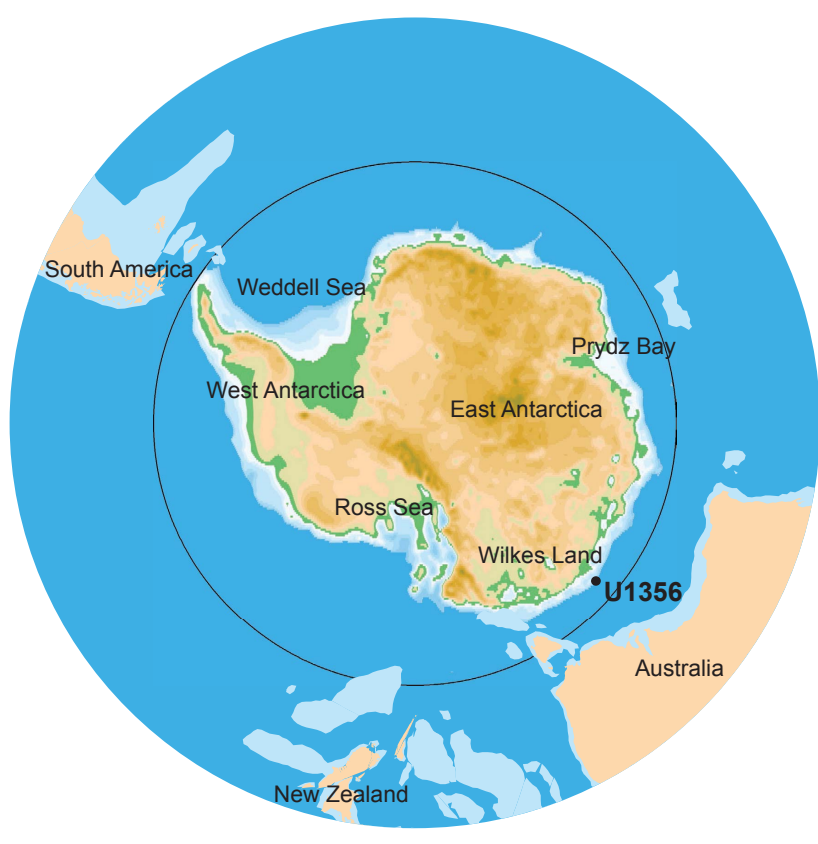

Figure 1. Location of IODP Expedition 318 Site U1356 during the Eocene-Oligocene transition adapted from Houben et al. (2013). Pale blue areas indicate shelf environments and green areas show lowland regions in Antarctica. The black circle is located at $60^{\circ} \mathrm{S}$. Antarctic topography and palaeoceanography modified after Lawver and Gahagan (2003) and Wilson et al. (2012).

provides an opportunity to assess whether sporomorphs in a sediment record are non-reworked or reworked from older strata. Antarctic Cenozoic sediments typically show a complex burial history, with episodes of glacial erosion and rapid sediment deposition. The Wilkes Land Site U1356 shows shifts in the delivery of sediments to the site (e.g. shift in depocenters, changes in the amount and type of sediment delivered to the site) and erosion during two major events near the Eocene-to-Oligocene and Oligocene-to-Miocene transitions (see also Sect. 3). The alternating phases of erosion, accumulation, and rapid deposition have a strong impact on the fluorescence of each individual palynomorph and the assemblage. We addressed these factors by building our experimental approach on the following assumptions:

i. Each palynomorph assemblage contains a strongly varying percentage of reworked pollen and spores, which can originate from multiple sources and ages.

ii. Changes in fluorescence are site- and sediment-specific, which prevents the use of fluorescence data for absolute age determinations and a comparison of the fluorescence values between sites.

iii. Fluorescence values in consecutive sediment layers can overlap and are strongly variable. iv. Discrimination of non-reworked palynomorphs can only be based on relative measurements and not on absolute values taken from single strata and single grains.

We hypothesize that the presence of non-reworked palynomorphs in a sediment core will result in a fluorescence signal that continuously declines with increasing depth. We further hypothesise that significantly different values between depths indicate the presence of a sufficiently high number of non-reworked pollen and spores to be used for a meaningful environmental reconstruction.

\section{Sedimentology of Site U1356 and potential source of reworking}

Pollen and spores were examined from Eocene, Oligocene, and Miocene sediments from IODP Site U1356 located $\sim 300 \mathrm{~km}$ off Wilkes Land, East Antarctica $\left(63^{\circ} 18.6138^{\prime} \mathrm{S}\right.$, $135^{\circ} 59.9376^{\prime} \mathrm{E}$ ), at the transition between the continental rise and the abyssal plain (Fig. 1; Escutia et al., 2014). The Wilkes Land margin formed during the late Cretaceous as part of a non-volcanic rift, with Oligocene-Eocene shelf sediments exposed today on the continental shelf proximal to Site U1356 (Close et al., 2009; Expedition 318 Scientists, 2011). The sediments at Site U1356 (Fig. 2) record a complex history in the development of this margin that has been deeply influenced by the growth of a continental-scale ice sheet during the Eocene-Oligocene transition (EOT) and by ice-ocean interactions since the earliest Oligocene.

During the early and middle Eocene, sedimentation took place in a shallow-water environment largely influenced by delivery of sediments from the continent. The lowermost interval (949-1006 m below seafloor, mb.s.f.) dated early Eocene consists of bioturbated claystones likely deposited by hemipelagic sedimentation. Rare laminated siltstone and sandstone interbeds indicate sporadic gravity flows or bottom current activity reaching the site. Sedimentary environments during the middle Eocene (895-949 m b.s.f.) are characterized by the presence of sandstones with clasts and contorted bedding, diamictites, and micaceous fining-upwards sandstones and siltstones, which point to deposition in a shallowwater environment. The clay fraction in all Eocene sediments contains smectite and kaolinite (Expedition 318 Scientists, 2011), which points to chemical weathering under warm and humid conditions (Expedition 318 Scientists, 2011).

During the EOT, subsidence and the glacial isostatic adjustment of the margin resulted in partial eustatic recovery on the continental shelf and erosive currents on deeper parts of the margin (Stocchi et al., 2013). At Site U1356, the non-glacial middle Eocene strata are separated from early Oligocene glaciomarine strata by the WL-U3 regional unconformity (Fig. 2; Escutia et al., 2005, 2011). This unconformity represents a 13-million-year (Myr) hiatus (Escutia et al., 2011; Tauxe et al., 2012) suggested to predominately be caused by an extreme erosion event associated with the 


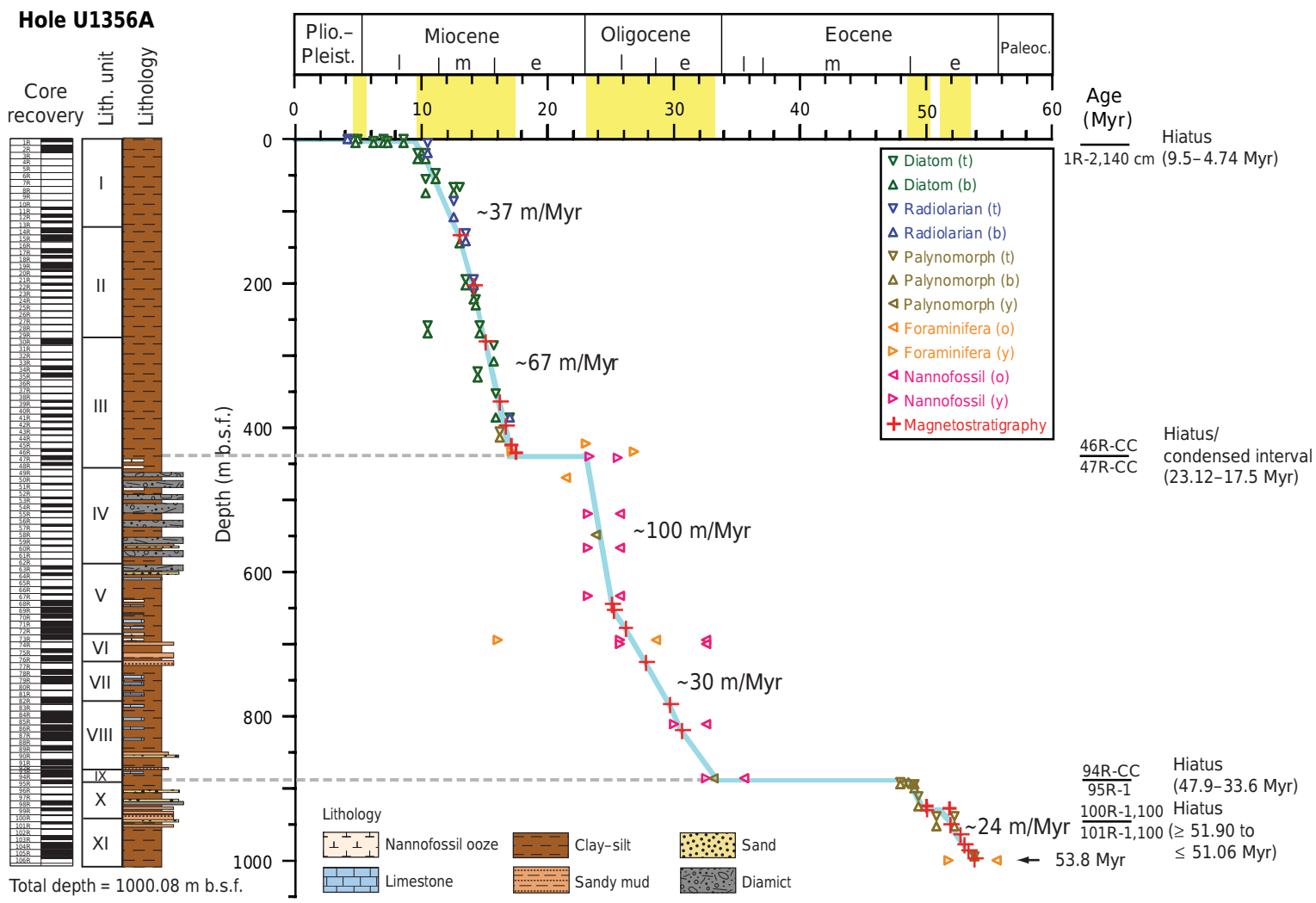

Figure 2. Age-depth plot and lithostratigraphic summary for Site U1356, after Tauxe et al. (2012) and Escutia et al. (2011).

growth of a continental-wide ice sheet during the EOT leading to the Oi-1 event (Escutia et al., 2011, 2014). On the continental shelf, approximately $300-600 \mathrm{~m}$ of sediment was eroded during the Oi-1 event (Eittreim et al., 1995), but partial eustatic recovery provided accommodation space for early Oligocene sediments (Escutia et al., 2011), and potentially late Eocene sediments (Stocchi et al., 2013), to accumulate.

High sedimentation rates during the Oligocene resulted in approximately $455 \mathrm{~m}$ (440.7-895.41 m b.s.f.) of sedimentary strata being deposited at Site U1356, dated as early to late Oligocene ( 33.6-23 Myr) (Escutia et al., 2011; Tauxe et al., 2012). Oligocene sediments all denote deposition in deep-water environment, with occasional reach of iceberg activity indicated by dropstones (Escutia et al., 2011). Sedimentation rates during the early Oligocene (723.5$895 \mathrm{~m}$ b.s.f.) section are $20 \mathrm{~m} \mathrm{Myr}^{-1}$ and lithologies are characterized by interbedded, laminated claystones; bioturbated claystones; contorted diamictites; convoluted, bedded mudstones (Expedition 318 Scientists, 2011). These sediments indicate that times of hemipelagic sedimentation with the influence of bottom currents alternate with times dominated by mass-transport deposits (MTDs). The presence of turbidites and MTDs points to times with an increased contribution of transported sediment from shallow-marine and ultimately terrestrial sources, indicating a strong likelihood of reworked palynomorphs in the record. The late Oligocene (459.4-723.5 m b.s.f.) is characterized by a sharp increase in sedimentation rates $\left(89 \mathrm{~m} \mathrm{Myr}^{-1}\right)$. The sedimentary section is comprised by an alternation of bioturbated claystones with laminated claystones indicative of hemipelagic deposition influenced by bottom currents of varying velocities. Interbedded with the claystones are diamictites, graded siltstones, and sandstones, indicative of the deposition of end members of subaqueous density flows (turbidite, debris flow, MTDs), pointing to an increase in terrigenous sediment to the site (Expedition 318 Scientists, 2011).

The late Oligocene and early-to-middle Miocene (23.1216.7 Myr) are separated by a $\sim 6 \mathrm{Myr}$ long hiatus (Escutia et al., 2011). The Miocene sedimentary section includes bioturbated claystones, siltstones and sandstones (Expedition 318 Scientists, 2011). The late-middle Miocene section is characterized by diatom ooze and laminated diatom-rich silty clay, indicating that the high-biogenic and low-terrigenous hemipelagic sedimentation that dominates in a relatively high-productivity environment is also affected by bottomcurrent activity. The pebble-sized clasts and coarse sand clusters or interbeds likely indicate ice rafting. The middle Miocene section below $278 \mathrm{~m}$ b.s.f. shows an increase in bioturbation and a lack of gravel-sized clasts, suggesting minimal iceberg rafting. Sedimentation rates during Miocene are around $80 \mathrm{~m} \mathrm{Myr}^{-1}$ but significantly decrease after $12 \mathrm{Myr}$. 

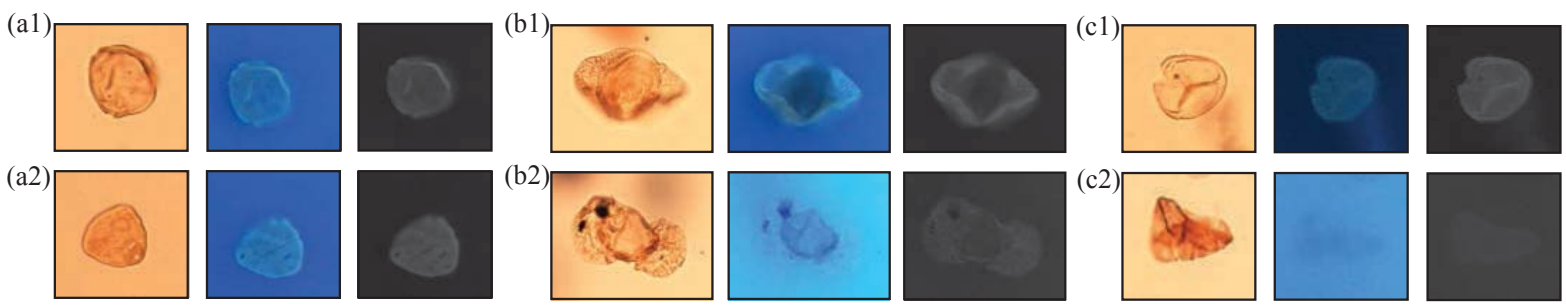

(a3)
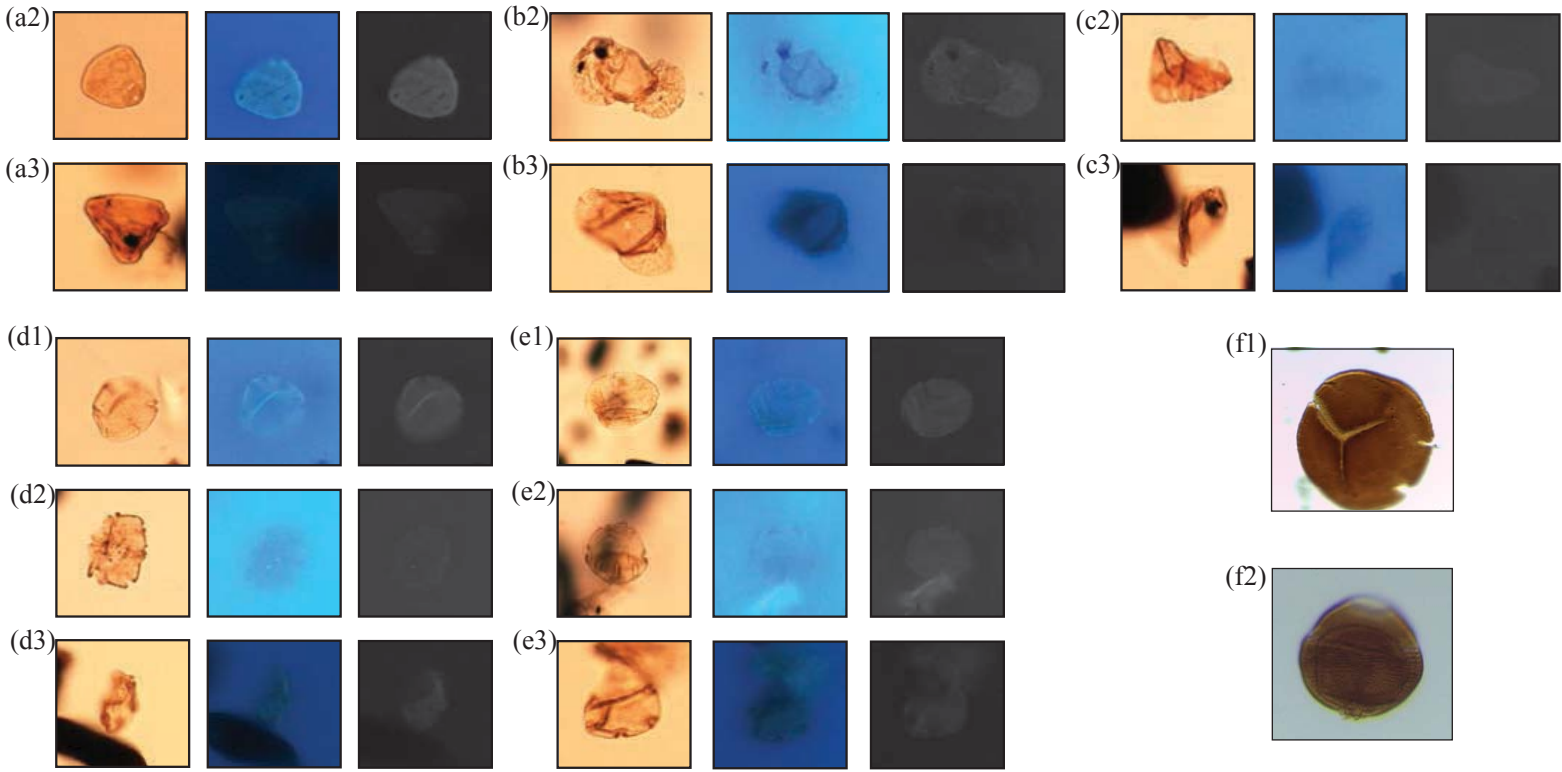

(f1)

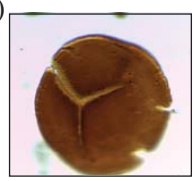

(f2)

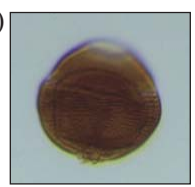

Figure 3. Images of Eocene, Oligocene, and Miocene pollen and spore taxa analysed under white light, UV fluorescence, and red filter. The red filter shows better contrast between the grain and the background. (a) Myricipites harrisii: (a1) Miocene, slide 15R-6W, 20-22 cm; (a2) Oligocene, slide 84R-1W, 44-48 cm; (a3) Eocene, slide 106R-2W, 80-83 cm. (b) Podocarpidites ellipticus: (b1) Miocene, slide 35R-2W, 20-22 cm; (b2) Oligocene, 85R-3W, 20-24 cm; (b3) Eocene, 103R-4W, 120-124 cm. (c) Cyathidites minor: (c1) Miocene, slide 15R-6W, 20-22 cm; (c2) Oligocene, slide 50R-1W, 24-30 cm; (c3) Eocene, slide 103R-4W, 120-121 cm. (d) Nothofagidites lachlaniae: (d1) Miocene, slide 22R-2W, 20-22 cm; (d2) Oligocene, slide 87R-5W, 40-44 cm; (d3) Eocene, slide 97R-1W, 60-63 cm. (e) Nothofagidites flemingii: (e1) Miocene, slide 12R-2W, 20-22 cm; (e2) Oligocene, slide 59R-1W, 17-19 cm; (e3) Eocene, slide 99R-2W, 40-43 cm. (f) Reworked palynomorphs not included in fluorescence measurements; (f1) reworked trilete spore, Oligocene, slide 52R-CCW, 9-13 cm. (f2) Classopollis chateaunovi: Oligocene, slide 93R-1W, 64-68 cm.

\section{Methods}

\subsection{Palynological sampling and preparation}

Pollen taxa were analysed from 28 samples between 106.62 and $998.99 \mathrm{~m}$ b.s.f. (see Table S1). All samples were processed at the Laboratory of Palaeobotany and Palynology, Utrecht University, The Netherlands, using their standard palynological processing method for marine sediments (e.g. Bijl et al., 2013). Samples were treated with $10 \% \mathrm{HCl}$ and cold $38 \%$ HF to dissolve carbonates and silicates respectively and again with $10 \% \mathrm{HCl}$ to eliminate silica gel, and they were sieved with a $10 \mu \mathrm{m}$ mesh. Residues were mounted on glass microscope slides using glycerine jelly, and the edges were sealed with nail polish. The nail polish seems to limit the fluorescence of the underlying palynomorphs due to the additional medium diminishing the intensity of the brightness. Therefore, we chose to consider only those palynomorphs that were not close to the edges of the slide. The use of acids such as $\mathrm{HF}$ and $\mathrm{HCl}$ can alter the fluorescence of grains towards the red end of the spectrum (Van
Gijzel, 1971; Waterhouse, 1998). However, the same palynological processing techniques were uniformly used for all samples. For the Miocene, late Oligocene, early Oligocene, and Eocene, 30 pollen and spore grains were randomly selected to determine the fluorescence signatures through geological time. The aim of our study is to identify reworking in palynological assemblages over successive geological time periods. We therefore performed a preselection by removing obviously reworked, older-than-Eocene sporomorphs, which were extremely dark to almost opaque under a light microscope and had very little to no fluorescence under UV excitation (Fig. 3f1, f2). We only selected those pollen and spore grains as Eocene-Miocene palynomorphs that were light and translucent under a light microscope, with strong fluorescence under UV excitation, and not covered by other material on the slide (i.e. organic matter). This examination was done on all slides studied from the Eocene, early Oligocene, late Oligocene, and Miocene. Five common pollen and spore taxa, which are abundant in most Antarctic pollen records and also found in the majority of the Wilkes Land samples, were selected for analysis. Dependent on availability, 

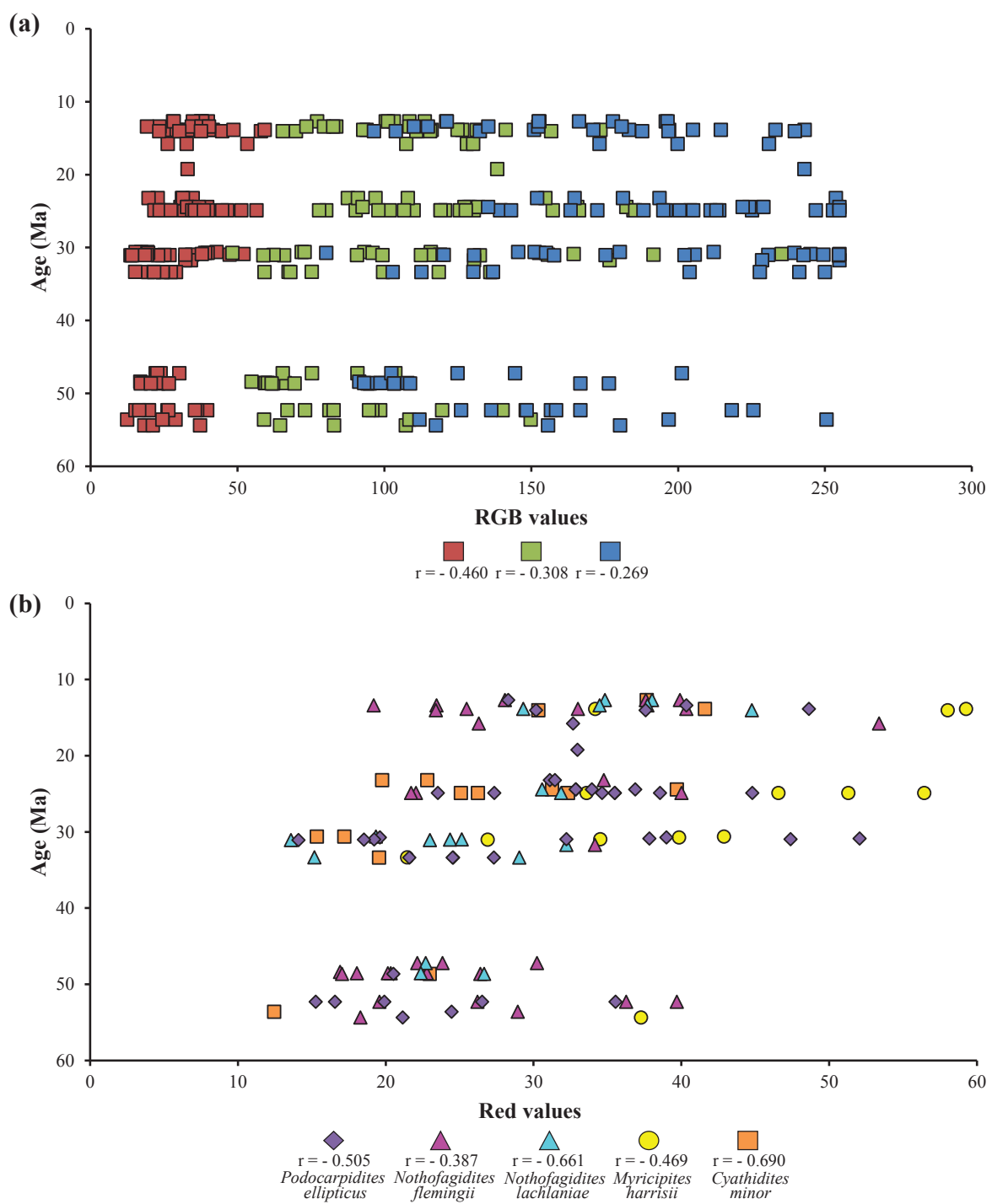

Figure 4. (a) All measured RGB fluorescence values for the 120 grains sampled in the Eocene, early Oligocene, late Oligocene, and Miocene plotted against age. The Pearson's correlation coefficient values of fluorescence variables show the strength of the relationship between each fluorescence colour (red, green, and blue) and age. (b) Red-fluorescence values of each measured grain categorized by taxon (Cyathidites minor, Myricipites harrisii, Nothofagidites flemingii, N. lachlaniae, Podocarpidites ellipticus) and plotted versus age along with Pearson's correlation coefficient to indicate the correspondence between the red values of each taxon and age.

the number of different taxa per time slice varied. These taxa include (name in brackets indicates potential nearest living relative after Raine et al., 2011, and Contreras et al., 2013) Cyathidites minor (Cyathea), Myricipites harrisii (Casuarinaceae or Myricaceae), Nothofagidites flemingii (Nothofagus), N. lachlaniae (Nothofagus), and Podocarpidites ellipticus (Podocarpus).

\subsection{Fluorescence microscopy}

The five pollen and spore taxa were examined under light and UV fluorescence using an Olympus BX40F microscope with a high-pressure mercury burner, dichronic mirror with a 330$385 \mathrm{~nm}$ exciter filter, and $420 \mathrm{~nm}$ long-pass barrier filter. The biochemical fluorescence emitted in Cenozoic sporomorphs ranges through the red, green, and blue light intensity spectrum (Bujak and Davies, 1982). Factors such as intensity, saturation, and brightness also affect the fluorescence emission and were measured to test whether these variables changed with age and depth. 
Pollen and spores emit fluorescence ranging from blue $(400 \mathrm{~nm})$ to red $(700 \mathrm{~nm})$, and the preservation of the exine helps to determine the fluorescence colour (Van Gijzel, 1971). For an initial qualitative colour classification of the investigated pollen and spores, the colour chart based on UV fluorescence by Yeloff and Hunt (2005) was used. When correlating the UV-fluorescence signal of sporomorph grains, only comparison between the same sporomorph taxa can be performed. This is due to variations in the chemical composition of the exine that affect the fluorescence colour of the grains (Hunt et al., 2007). The gain and exposures were standardized for all measured grains throughout the analysis to allow for accurate representation of the RGB values measured. For the light microscope the gain was $1.00 \times$ and the exposure $20 \mathrm{~ms}(+2.0 \mathrm{EV})$, while under fluorescence the gain stayed at $1.70 \times$ and the exposure was $100 \mathrm{~ms}(+2.0 \mathrm{EV})$. The white balance $(1.30,1.00,2.00)$ was constant through the entire process. Pictures were taken using a Nikon DSFi1 camera and were analysed in image processing software (NIS-Elements Basic Research 3.0 program). The RGB, intensity, saturation, and brightness values were measured for each grain under light and UV fluorescence. This was in relation to a greyscale from 0 (no light) to 256. The values were taken from each grain through an autodetect tool, which draws a contour around the grain. From this contour the program provides a mean value of the grain, i.e. each fluorescence pixel value from around the contour of the grain. The total fluorescence value for each individual grain was then applied to statistical evaluation.

\subsection{Statistical analyses}

To quantitatively assess the fluorescence behaviour of the five taxa from Site U1356, three different statistical approaches were used:

A Pearson's correlation coefficient $(r)$ was calculated to determine whether the fluorescence measurements of sporomorphs correlate with age. This correlation coefficient shows the strength of the relationship from independently measured fluorescence variables against age through the Eocene to the Miocene. Coefficient values that are closer to 1 or -1 show a better linear agreement. The most statistically significant fluorescence value, red, was then measured for each taxon to indicate the correspondence of red taxa values against age. This was undertaken in IBM SPSS Statistic version 22. For determining if correlation results are statistically relevant, the highest significance level of $p$ values (0.01) was used.

The Mann-Whitney $U$ test was performed in PAST software (Hammer et al., 2001) to compare whether two datasets that are not normally distributed are statistically different from one another. Like other marine cores from the Antarctic shelf (e.g. Askin and Raine, 2000; Anderson et al., 2011), the sediments from U1356 have a comparatively low pollen concentration, in particular in the Oligocene and Miocene sections deposited after the growth of a continental-wide ice sheet during the EOT. The overall number of palynomorphs suitable for fluorescence measurements were therefore limited and varied between samples. However, to assess statistically significant differences between samples, we chose the Mann-Whitney $U$ test, which is applicable to all sample sizes and may be used with as few as four measurements in each sample (Fowler et al., 2009). The datasets being compared are sporomorph fluorescence measurements (red, brightness, and intensity) of successive geological time slices (e.g. late Oligocene vs. Miocene red values). For each value in one sample, the number of values in a second sample are counted when the value is smaller than the first sample (ties are counted as 0.5). The total of these counts are the $U$ statistic (Hammer et al., 2001). For larger sample values $(n=30)$, an asymptotic approximation to $p$ value based on normal distribution is used. Smaller values of the $U$ statistic would support the separation of fluorescence measurements between time steps, and larger $U$ values would support the null hypothesis, indicating the groups are similar (Hammer et al., 2001). This tests if a statistically significant fluorescence signature can be identified to separate sporomorphs over subsequent geological epochs in the Wilkes Land core. The fluorescence variables red, brightness, and intensity were chosen because these values had the strongest linear relationship against age (high $r$ values) from the Pearson correlation tests.

To determine if similar fluorescence values of palynomorphs can be grouped by age, burial depth, taxonomy, or fluorescence colour, a series of one-way analysis of similarities tests (ANOSIM), with 999 permutations, were conducted using PRIMER 6 (Clarke and Gorley, 2006). The raw fluorescence data for the 120 measured palynomorphs were first pretreated with a square root transformation, and then a resemblance matrix was constructed using the Bray-Curtis similarity algorithm. Using ANOSIM tested if palynomorphs with similar fluorescence values (intensity, RGB, saturation, and brightness) could be grouped into categorical factors: age - Eocene, early Oligocene, late Oligocene, Miocene; burial depth; taxonomy (Cyathidites minor, Myricipites harrisii, Nothofagidites flemingii, $N$. lachlaniae, Podocarpidites ellipticus); and fluorescence light colour (yellow, orange, and red). ANOSIM tests the null hypothesis that there are no fluorescence differences between samples grouped by the levels of a factor (e.g. fluorescence values for an Eocene sample would be distinct from a Miocene sample). If the global $R$ is close to 0 , then fluorescence values characterized by different levels of a factor (e.g. Eocene, early Oligocene, late Oligocene, Miocene) are similar and the hypothesis that the age of the sample determines the fluorescence (in this example) can be rejected. Conversely, the closer the global $R$ value is to 1 , the more strongly that factor explains the separation of the similar fluorescence values (Clarke and Gorley, 2006). 
Table 1. Pearson's correlation coefficient values of the (a) fluorescence variables (RGB, intensity, brightness, and saturation) and (b) red values of each taxon measured, along with sample size, mean, standard deviation (SD), and $p$ values.

\begin{tabular}{lrrrrr}
\hline (a) Fluorescent variables & $N$ & Mean & SD & $\begin{array}{r}\text { Pearson correlation } \\
\text { coefficient }(r)\end{array}$ & $p$ value \\
\hline Red & 120 & 30.08 & 10.08 & -0.460 & 0.0001 \\
Green & 120 & 107.11 & 35.45 & -0.308 & 0.0006 \\
Blue & 120 & 179.40 & 50.14 & -0.269 & 0.0030 \\
Intensity & 120 & 105.53 & 29.94 & -0.323 & 0.0003 \\
Brightness & 120 & 41.38 & 11.74 & -0.323 & 0.0003 \\
Saturation & 120 & 180.82 & 19.24 & 0.220 & 0.0158 \\
\hline (b) Species red values & $N$ & Mean & SD & Pearson correlation & $p$ value \\
& & & & coefficient $(r)$ & \\
\hline Podocarpus ellipticus & 41 & 30.44 & 9.29 & -0.505 & 0.0007 \\
Nothofagidites lachlaniae & 19 & 28.17 & 8.03 & -0.661 & 0.0020 \\
Nothofagidites flemingii & 32 & 27.81 & 8.82 & -0.387 & 0.0290 \\
Myricipites harrisii & 13 & 41.72 & 12.03 & -0.469 & 0.1057 \\
Cyathidites minor & 15 & 26.29 & 8.97 & -0.690 & 0.0044 \\
\hline
\end{tabular}

\section{Results}

\subsection{Subjective assessment of sporomorphs through fluorescence colours}

A subjective assessment of the sporomorphs fluorescence signature revealed that a purely visual estimate of fluorescence colour only allows a limited identification of reworking and separation of geological ages. Following the colour chart classification of Yeloff and Hunt (2005), each colour was assigned a number, with Eocene pollen and spores generally graded from an orange to red (46-49), while Oligocene grains fluoresced an orange to yellow colour (43-46), and Miocene grains showed similar yellow to light orange fluorescence (42-45) (see also Supplement). The visual examination and identification of the fluorescence colour of a pollen or spore grain can vary depending upon the observer, and the fluorescence colour of sporomorphs overlaps through time (Bujak and Davies, 1982). The visible red colour fluorescence clearly distinguishes Eocene sporomorphs from Oligocene and Miocene grains in the Site U1356 material, shown from the contrast between pollen and spore grains and the slide background under a red filter (Fig. 3). However, the subjective colour comparison of fluorescence alone could not distinguish between Oligocene and Miocene grains (Fig. 3; see Table S1).

\subsection{Variation of fluorescence values through the Eocene to Miocene}

The Pearson's correlation $(r)$ coefficient indicates a moderate to strong relationship between red-fluorescence values, intensity, brightness, and geological age. Red values showed the strongest statistical correlation with age values, $r=-0.46(p<0.0001)$ (Table 1a; Fig. 4a). Due to the mod- erate to very strong relationship between total red values and age, a Pearson's correlation was also performed on each taxon's red value (Table 1b; Fig. 4b). A very strong agreement includes Cyathidites minor $(r=-0.69, p=0.004)$ and Nothofagidites lachlaniae $(r=-0.66, p=0.002)$, with Podocarpidites ellipticus ( $r=-0.51, p=0.0007)$ showing a moderate correlation between red values and age (Table $1 \mathrm{~b}$; Fig. 4b). Brightness and intensity had a moderate correlation with age, $r=-0.32$, but high significance ( $p=0.0003$ ), whereas saturation values showed no relationship with age $(r=0.22)$. Green $(r=-0.31, p=0.0006)$ and blue values $(r=-0.27, p=0.003)$ had a weak relationship to age with high significance. Pearson's correlation indicates red fluorescence, intensity, and brightness as the most statistically significant fluorescence signatures to separate non-reworked sporomorphs in the Wilkes Land core.

The Mann-Whitney $U$ tests show statistically highly significant $(p<0.0001)$ changes of red-fluorescence, intensity, and brightness values from the Eocene to late Oligocene and the Eocene to Miocene (Table 2). However, there is no statistically considerable difference between the Eocene and early Oligocene red values $(p=0.2772)$, whereas significant differences exist between the intensity $(p=0.0014)$ and brightness $(p=0.0014)$ (Table 2$)$. The early Oligocene to Miocene ( $p=0.0009)$ and early Oligocene to late Oligocene ( $p=0.0067)$ red signals can be distinguished from one another (Table 2); however, the intensity and brightness cannot. The late Oligocene to Miocene red fluorescence ( $p=$ $0.2772)$, intensity ( $p=0.0451)$, and brightness ( $p=0.0459)$ cannot be differentiated from each other. This indicates that measuring the red-fluorescence values from the Wilkes Land samples can distinctively separate the fluorescence signal from sporomorphs in the Eocene, Oligocene, and Miocene. The Mann-Whitney $U$ test indicates that non-successive 
Table 2. Mann-Whitney $U$ test values correlating the red fluorescence, intensity, and brightness throughout the Eocene to the Miocene. Larger $U$ statistic values indicate fluorescence similarity and smaller $U$ statistic values show greater separation of fluorescence between time steps.

\begin{tabular}{|c|c|c|c|c|c|c|c|c|c|c|c|c|c|}
\hline \multicolumn{2}{|c|}{ Age comparison } & \multicolumn{4}{|c|}{ Red } & \multicolumn{4}{|c|}{ Intensity } & \multicolumn{4}{|c|}{ Brightness } \\
\hline & & $U$ & $n_{1}$ & $n_{2}$ & $p$ value & $U$ & $n_{1}$ & $n_{2}$ & $p$ value & $U$ & $n_{1}$ & $n_{2}$ & $p$ value \\
\hline Miocene & Late Oligocene & 376 & 30 & 30 & 0.2772 & 314 & 30 & 30 & 0.0451 & 315 & 30 & 30 & 0.0459 \\
\hline Late Oligocene & Early Oligocene & 266 & 30 & 30 & 0.0067 & 357 & 30 & 30 & 0.1715 & 357 & 30 & 30 & 0.1714 \\
\hline Early Oligocene & Eocene & 376 & 30 & 30 & 0.2772 & 234 & 30 & 30 & 0.0014 & 234 & 30 & 30 & 0.0014 \\
\hline Late Oligocene & Eocene & 166 & 30 & 30 & 0.0001 & 126 & 30 & 30 & 0.0001 & 126 & 30 & 30 & 0.0001 \\
\hline Miocene & Eocene & 121 & 30 & 30 & 0.0001 & 200 & 30 & 30 & 0.0001 & 200 & 30 & 30 & 0.0001 \\
\hline Early Oligocene & Miocene & 224 & 30 & 30 & 0.0009 & 419 & 30 & 30 & 0.6520 & 419 & 30 & 30 & 0.6520 \\
\hline Oligocene & Eocene & 293 & 30 & 30 & 0.0207 & 145 & 30 & 30 & 0.0001 & 145 & 30 & 30 & 0.0001 \\
\hline Oligocene & Miocene & 271 & 30 & 30 & 0.0083 & 326 & 30 & 30 & 0.0679 & 326 & 30 & 30 & 0.0679 \\
\hline
\end{tabular}

intervals in geological time, e.g. Eocene to Miocene and Eocene to late Oligocene, show more distinctive differences in red-fluorescence, intensity, and brightness values. However, unlike the subjective fluorescence colour comparison, the Mann-Whitney $U$ test shows that Oligocene and Miocene grains can now be separated based on the digital quantitative measurement of their red-fluorescence signature.

\subsection{Factors potentially influencing fluorescence sporomorph signals}

To understand if geological age (e.g. Eocene, Oligocene, and Miocene), fluorescence colour of palynomorphs, burial depth, and number of taxa had any influence on the similarity of fluorescence values, an ANOSIM analysis was done calculating global $R$ values for each factor. The ANOSIM tests demonstrated that the age (Eocene, Oligocene, and Miocene) of a sample (global $R=0.145, P=0.001$ ) and the burial depth (global $R=0.315, P=0.001$ ) could explain the separation of samples with similar fluorescence into factors (see Table S2). This shows that both age and depth (age being a function of depth in this study) influence the fluorescence of palynomorphs. The taxonomy of the samples (i.e. number of taxa) could not explain any similarity in fluorescence values (global $R=0.006, P=0.385$ ) and neither could the fluorescence colour of the palynomorph (global $R=0.085$ $P=0.011)$.

\section{Discussion}

\subsection{The advantage of applying a quantitative approach and red fluorescence}

Our approach provides a new, essential, and simple tool to identify non-reworked palynological assemblages in marine sediment records from high latitudes that are influenced by glaciation and extensive reworking. Our study also highlights the importance of using a quantitative approach in combination with digital imaging software to identify nonreworked palynomorph assemblages over successive geological timescales. The quantitative approach does not only offer a reproducible and transferable method. By detecting significant differences between the Oligocene and Miocene in the Wilkes Land core, this method has proven to be able to identify non-reworked palynomorph assemblages, which cannot be identified by using qualitative and subjective colour comparisons alone. Subjective fluorescence microscopy has been applied to separate non-reworked grains from recycled Permian-lower Mesozoic sporomorphs in the early Miocene Cape Roberts Project (CRP) 1 core (Raine, 1998). Neither transmitted light (yellow to yellow-brown) nor fluorescence colour (yellow to orange) comparisons could discern Cenozoic pollen and spores (Raine, 1998; Askin and Raine, 2000; Raine and Askin, 2001). There is no apparent pattern of variation found in the fluorescence colour of sporomorphs in assemblages from the Ross Sea, emphasizing the importance of taking quantitative fluorescence measurements.

Our quantitative approach identified among the various fluorescence values (i.e. red, blue, green, brightness, saturation, and intensity), the red fluorescence of pollen and spores as the most reliable indicator to differentiate reworking in successive geological epochs. From the Eocene through the Miocene, each time step shows a clear statistical grouping of red-fluorescence values of pollen and spores. While individual taxa do show varying overlaps in red-fluorescence values (Fig. 4b), all five pollen and spore taxa show a moderate to strong relationship with age (Fig. 4), reducing the likelihood of large amounts of reworked grains being present in the respective taxa assemblages. The Neogene sediment section of Site U1356 is expected to have significant reworking due to the submarine exposure of Eocene sediments close to the site. However, by using red fluorescence, our approach was able to clearly distinguish between the Paleogene and Neogene pollen assemblages. 


\subsection{Influence of heat flow, burial depth, and hiatuses on fluorescence}

In order for a distinct fluorescence signature to be unambiguously identified in a palynological assemblage, an ample amount of geological time between samples is needed (e.g. Van Gijzel, 1967; Bujak and Davies, 1982). It is important to discern whether fluorescence values can be distinguished over successive geological intervals and how factors such as hiatuses and burial depth can possibly affect fluorescence. The largest differences in depth and intervals of geological time in the Wilkes Land core are between the Eocene to late Oligocene and the Eocene to Miocene, and these intervals show the highest significance of red-fluorescence, intensity, and brightness values ( $p<0.0001$; Table 2$)$. However, geological age alone does not always determine the fluorescence signal of sporomorphs. The amount and length of exposure to burial heat ultimately establishes the fluorescence alteration of sporomorphs (Waterhouse, 1998). Red-fluorescence values are still significantly different $(p=0.0067$; Table 2$)$ when comparing the early and late Oligocene pollen assemblages. The oldest early Oligocene sample analysed was taken at $795.58 \mathrm{~m}$ b.s.f. and the youngest late Oligocene sample was analysed at $555.19 \mathrm{~m}$ b.s.f. This difference in sedimentation rate and ultimately burial depth could contribute to the differentiation of red values between the early and late Oligocene. Burial depth is shown to play an important role in the fluorescence of sporomorphs, as also indicated by the global $R$ value in the ANOSIM analysis (Sect. 3.3).

Disruption of sporomorph exposure to burial heat is shown to have an effect on fluorescence red values as well. Between the mid-Eocene to early Oligocene and the late Oligocene to Miocene, the differences in red values are non-significant $(p=0.2772$; Table 2). There are two major hiatuses observed in the Eocene to Miocene sediment record of Site U1356 (Escutia et al., 2011). A $\sim 13 \mathrm{Myr}$ hiatus is found between the middle Eocene and the early Oligocene (Escutia et al., 2014). This unconformity represents extensive erosion correlating with the onset of glaciation at the EoceneOligocene boundary (Escutia et al., 2011, 2014; Stocchi et al., 2013). Another hiatus correlates with a regional unconformity at Wilkes Land that coincides with the Mi-1 event and extends from $\sim 23.12$ to $16.7 \mathrm{Myr}$ (Escutia et al., 2005, 2011). The hiatuses in the Wilkes Land core could have potentially disrupted the sporomorphs exposure to burial heat, causing a less-distinctive fluorescence signature between the mid-Eocene to early Oligocene and late Oligocene to Miocene. However, it is important to reiterate that our study could still find significant differences in red fluorescence between the entire Oligocene and Miocene $(p=0.0083)$.

\subsection{Fluorescence variation between taxa}

In order to produce comparable values for each geological time interval, our fluorescence approach requires sedi- ment cores spanning successive geological epochs with similar palynological assemblages. The Paleogene and Neogene Antarctic palaeovegetation are unique, with a number of common taxa (e.g. Nothofagidites and Podocarpidites) still present in palynological assemblages through a major climatic change from a greenhouse to icehouse world (e.g. Truswell and Macphail, 2009; Pross et al., 2012; Griener et al., 2015). When comparing the fluorescence signature between geological time intervals, the same taxa must be used. Differences between the fluorescence signatures of individual taxa in the Wilkes Land assemblage are apparent (Fig. 4; Table 1). Factors such as exine composition and differential sensitivity to thermal alteration can cause variation in fluorescence measurements between sporomorph taxa (Waterhouse, 1998). The differences in red-fluorescence signature could also have occurred due to variation in the number of taxa measured for each geological time slice. The only spore taxa in this study, Cyathidites minor, showed the strongest correlation between fluorescence red values $(r=-0.69, p<$ $0.004)$ through geological time. This could be due to the chemical composition of Cyathidites minor, the thickened and complex perispore (Marquez and Morbelli, 2014) or due to how this spore chemistry reacts to degradation over geological time.

\section{Concluding remarks: applications and limitations of the quantitative red-fluorescence approach}

The unambiguous identification of non-reworked palynomorphs is a prerequisite for fully understanding the terrestrial vegetation response to periods of extensive cooling and environmental changes in Antarctica. Our study focussed on identifying non-reworked palynological assemblages from Antarctica, although this method can theoretically be applied to all palynological records. Our approach requires a sufficiently long palynological record (e.g. Miocene to Eocene) and the consistent presence of identical pollen taxa that occur in reasonable numbers in all measured time intervals. For statistical analysis, fluorescence values of samples covering successive timescales in a single core (e.g. Eocene red values against Oligocene red values) must be measured using digital imaging software. A preselection removing obviously reworked grains (e.g. grains older than the successive timescales that are extremely dark to opaque under a light microscope) from the analysis needs to be performed. Suitable pollen and spore taxa that can be found throughout the core over successive timescales must be determined before fluorescence analysis. By using fluorescence microscopy, this study shows that red fluorescence is the most reliable parameter to statistically identify reworking on million-year timescales during the Paleogene and Neogene. The study also highlights intensity and brightness as sensitive indicators. It is important to emphasize that the red-fluorescence values from this study are not absolute and are specific to 
the Wilkes Land core. Fluorescence variation between taxa is apparent.

Our study offers a new quantitative approach to identifying if a sediment core contains non-reworked pollen taxa assemblages to reconstruct Cenozoic climate change and vegetation pre- and post-Antarctic cryosphere formation with high confidence. By using the Mann-Whitney $U$ test, the approach is suitable to work with low pollen concentrations that are very common in Antarctic palynology. However, a higher number of palynomorphs and fluorescence measurement would certainly increase the potential and depth of further statistical analyses. The low pollen number, for example, prevented us from exploring whether changes in the variance of the fluorescence value can be used as a measure for the degree of reworking in each sample (i.e. high variance means a high number of reworked palynomorphs). Additional studies are needed to systematically explore the wider use of our redfluorescence approach for Antarctic palynology. These studies should include forthcoming IODP drilling expeditions and possibly existing sites such as ANDRILL (AND-2A), where several taxa such as the Nothofagus, Proteaceae, and podocarp conifers were denoted with uncertainty because it is unknown when these taxa disappeared from Antarctica (Griener et al., 2015).

Data availability. The raw data generated in this study are available in the Supplement.

\section{The Supplement related to this article is available online at doi:10.5194/bg-14-2089-2017-supplement.}

Competing interests. The authors declare that they have no conflict of interest.

Acknowledgements. This study was funded by the Faculty of Engineering and Environment Research Studentship from Northumbria University. The samples used for this research were provided by the Integrated Ocean Drilling Program (IODP). Ulrich Salzmann acknowledges funding received from the Natural Environment Research Council (NERC grant NE/H000984/1). Francesca Sangiorgi thanks the Netherlands Organisation for Scientific Research (NWO) for NNPP Polar 866.10.110. Peter K. Bijl acknowledges the Dutch National Organisation for Scientific Research (NWO) for VENI grant no. 863.13.002. Carlota Escutia thanks the MINECO for scientific research grant CTM2014-60451-C2-1-P. Jörg Pross acknowledges support through the German Science Foundation (DFG; grant PR 651/10). We would finally like to thank the anonymous reviewer and Michael Hannah for their useful comments, which helped us to further improve this paper.

Edited by: M. van der Meer

Reviewed by: M. Hannah and one anonymous referee

\section{References}

Anderson, J. B., Warny, S., Askin, R. A., Wellner, J. S., Bohaty, S. M., Kirshner, A. E., Livsey, D. N., Simms, A. R., Smith, T. R., Ehrmann W., Lawver, L. A., Barbeau, D., Wise, S. W., Kulhanek, D. K., Weaver, F. M., and Majewski, W.: Progressive Cenozoic cooling and the demise of Antarctica's last refugium, P. Natl. Acad. Sci. USA, 108, 11356-11360, doi:10.1073/pnas.1014885108, 2011.

Askin, R. A. and Raine, J. I.: Oligocene and Early Miocene Terrestrial Palynology of the Cape Roberts Drillhole CRP-2/2A, Victoria Land Basin, Antarctica, Terra Antarctica, 7, 493-501, 2000.

Bijl, P. K., Bendle, J. A., Bohaty, S. M., Pross, J., Schouten, S., Tauxe, L., Stickley, C. E., McKay, R. M., Röhl, U., Olney, M., Sluijs, A., Escutia, C., Brinkhuis, H., and Expedition 318 Scientists: Eocene cooling linked to early flow across the Tasmanian Gateway, P. Natl. Acad. Sci. USA, 110, 9645-9650, doi:10.1073/pnas.1220872110, 2013.

Birkenmajer, K. and Zastawniak, E.: Late Cretaceous-early Tertiary floras of King George Island, West Antarctica: their stratigraphic distribution and palaeoclimatic significance, in: Origins and Evolution of Antarctic Biota, Geological Society of London Special Publications, edited by: Crame, J. A., 47, 227-240, 1989.

Bujak, J. P. and Davies, E. H.: Fluorescence and the search for petroleum, Annu. Rev., 1982, 54-57, 1982.

Clarke, K. R. and Gorley, R. N.: PRIMER v6: User Manual/Tutorial, PRIMER-E Ltd, Plymouth, UK, 2006.

Close, D. I., Watts, A. B., and Stagg, H. M. J.: A marine geophysical study of the Wilkes Land rifted continental margin, Antarctica, Geophys. J. Int., 177, 430-450, 2009.

Contreras, L., Pross, J., Bijl, P. K., Koutsodendris, A., Raine, J. I., van de Schootbrugge, B., and Brinkhuis, H.: Early to middle Eocene vegetation dynamics at the Wilkes Land Margin (Antarctica), Rev. Palaeobot. Palyno., 197, 119-142, doi:10.1016/j.revpalbo.2013.05.009, 2013.

Eittreim, S. L., Cooper, A. K., and Wannesson, J.: Seismic stratigraphic evidence of ice-sheet advances on the Wilkes Land margin of Antarctica, Sediment. Geol., 96, 131-156, doi:10.1016/0037-0738(94)00130-M, 1995.

Escutia, C., De Santis, L., Donda, F., Dunbar, R. B., Cooper, A. K., Brancolini, G., and Eittreim, S. L.: Cenozoic ice sheet history from East Antarctic Wilkes Land continental margin sediments, Global Planet. Change, 45, 51-81, doi:10.1016/j.gloplacha.2004.09.010, 2005.

Escutia, C., Brinkhuis, H., Klaus, A., and IODP Expedition 318 Scientists: IODP Expedition 318: From Greenhouse to Icehouse at the Wilkes Land Antarctic Margin, Scientific Drilling, 12, 15-23, doi:10.2204/iodp.sd.12.02.2011, 2011.

Escutia, C., Brinkhuis, H., and IODP Expedition 318 Scientists: From Greenhouse to Icehouse at the Wilkes Land Antarctic Margin: IODP Expedition 318 Synthesis of Results, in: Earth and Life Processes Discovered from subseafloor environments, edited by: Stein, R., Blackman, D., Inagaki, F., and Larsen, H.C., Developments in Marine Geology, 7, 2014.

Expedition 318 Scientists: Site U1356, in: Proceedings of the Integrated Ocean Drilling Program, edited by: Escutia, C., Brinkhuis, H., Klaus, A., the Expedition 318 Scientists, 318, 1103, doi:10.2204/iodp.proc.318.104.2011, 2011.

Fowler, J., Cohen, L., and Jarvis, P.: Practical statistics for field biology, 2nd Edn., John Wiley \& Sons, New York, 259 pp., 2009. 
Griener, K. W., Warny, S., Askin, R., and Acton, G.: Early to middle Miocene vegetation history of Antarctica supports eccentricity paced warming intervals during the Antarctic icehouse phase, Global Planet. Change, 127, 67-78, doi:10.1016/j.gloplacha.2015.01.006, 2015.

Hammer, Ø., Harper, D. A. T., and Ryan, P. D.: PAST: Paleontological statistics software package for education and data analysis, Palaeontol. Electron., 4, 1-9, 2001.

Houben, A. J., Bijl, P. K., Pross, J., Bohaty, S. M., Passchier, S., Stickley, C. E., Röhl, U., Sugisaki, S., Tauxe, L., van de Flierdt, T., Olney, M., Sangiorgi, F., Sluijs, A., Escutia, C., Brinkhuis, H., and Expedition 318 Scientists: Reorganization of Southern Ocean plankton ecosystem at the onset of Antarctic glaciation, Science, 340, 341-344, doi:10.1126/science.1223646, 2013.

Hunt, C. O., Rushworth, G., and Dykes, A. P.: UV-fluorescence microscopy and the coherence of pollen assemblages in environmental archaeology and Quaternary geology, J. Archaeol. Sci., 34, 562-571, doi:10.1016/j.jas.2006.06.011, 2007.

Lawver, L. A. and Gahagan, L. M.: Evolution of Cenozoic seaways in the circum-Antarctic region, Palaeogeogr. Palaeocl., 198, 1137, doi:10.1016/S0031-0182(03)00392-4, 2003.

Lewis, A. R., Marchant, D. R., Ashworth, A. C., Hedenäs, L., Hemming, S. R., Johnson, J. V., Leng, M. J., Machlus, M. L., Newton, A. E., Raine, J. I., Willenbring, J. K., Williams, M., and Wolfe, A. P.: Mid-Miocene cooling and the extinction of tundra in continental Antarctica, P. Natl. Acad. Sci. USA, 105, 10676-10680, 2008.

Marquez, G. J. and Morbelli, M. A.: Substructural components in the sporoderm of the Family Cyatheaceae, Palynology, 39, 248257, doi:10.1080/01916122.2014.948221, 2014.

Passchier, S., Bohaty, S. M., Jiménez-Espejo, F., Pross, J., Röhl, U., van de Flierdt, T., Escutia, C., and Brinkhuis, H.: Early Eocene to middle Miocene cooling and aridification of East Antarctica, Geochem. Geophy. Geosy., 14, 1399-1410, 2013.

Phillips, L.: An application of fluorescence microscopy to the problem of derived pollen in British Pleistocene deposits, New Phytol., 71, 755-762, 1972.

Pole, M., Hill, B., and Harwood, D. M.: Eocene plant macrofossils from erratics, McMurdo Sound, Antarctica, in: Paleobiology and Paleoenvironments of Eocene Rocks, edited by: Stillwell, J. D. and Feldmann, R. M., McMurdo Sound, East Antarctica. Antarctic Research Series, 76. American Geophysical Union, Washington D.C., 243-251, 2000.

Prebble, J. G., Raine, J. I., Barrett, P. J., and Hannah, M. J.: Vegetation and climate from two Oligocene glacioeustatic sedimentary cycles (31 and $24 \mathrm{Ma}$ ) cored by the Cape Roberts Project, Victoria Land Basin, Antarctica, Palaeogeogr. Palaeocl., 231, 41-57, doi:10.1016/j.palaeo.2005.07.025, 2006.

Pross, J., Contreras, L., Bijl, P. K., Greenwood, D. R., Bohaty, S. M., Schouten, S., Bendle, J. A., Röhl, U., Tauxe, L., Raine, J. I., Huck, C. E., van de Flierdt, T., Jamieson, S. S. R., Stickley, C. E., van de Schootbrugge, B., Escutia, C., Brinkhuis, H., and Integrated Ocean Drilling Program Expedition 318 Scientists: Persistent near-tropical warmth on the Antarctic continent during the early Eocene epoch, Nature, 488, 73-77, doi:10.1038/nature11300, 2012.

Raine, J. I.: Terrestrial Palynomorphs from Cape Roberts Project Drillhole CRP-1, Ross Sea, Antarctica, Terra Antarctica, 5, 539$548,1998$.
Raine, J. I. and Askin, R. A.: Terrestrial palynology of Cape Roberts Project Drillhole CRP-3, Victoria Land Basin, Antarctica, Terra Antarctica, 8, 389-400, 2001.

Raine, J. I., Mildenhall, D. C., and Kennedy, E. M.: New Zealand fossil spores and pollen: an illustrated catalogue, 4th Edn., GNS Science miscellaneous series no. 4, available at: http://data.gns cri.nz/sporepollen/index.htm (last access: 6 May 2016), 2011.

Salzmann, U., Riding, J. B., Nelson, A. E., and Smellie, J. L.: How likely was a green Antarctic Peninsula during warm Pliocene interglacials? A critical reassessment based on new palynofloras from James Ross Island, Palaeogeogr. Palaeocl., 309, 73-82, doi:10.1016/j.palaeo.2011.01.028, 2011.

Sangiorgi, F., Bijl, P. K., Passchier, S., Salzmann, U., Schouten, S., Pross, J., Bohaty, S. M., McKay, R., van de Flierdt, T., Levy, R., Williams, T., Escutia, C., and Brinkhuis, H.: Ocean warmth and the loss of marine-terminating East Antarctic ice sheets during the mid-Miocene Climate Optimum, in review, 2017.

Stocchi, P., Escutia, C., Houben, A. J. P., Vermeersen, B. L. A., Bijl, P. K., Brinkhuis, H., Deconto, R. M., Galeotti, S., Passchier, S., Pollard, D., and IODP Expedition 318 scientists: Relative sealevel rise around East Antarctica during Oligocene glaciation, Nat. Geosci., 6, 380-384, doi:10.1038/NGEO1783, 2013.

Tauxe, L., Stickley, C. E., Sugisaki, S., Bijl, P. K., Bohaty, S. M., Brinkhuis, H., Escuita, C., Flores, J. A., Houben, A. J. P., Iwai, M., Jiménez-Espejo, F., McKay, R., Passchier, S., Pross, J., Riesselman, C. R., Röhl, U., Sangiorgi, F., Welsh, K., Klaus, A., Fehr, A., Bendle, J. A. P., Dunbar, R., Gonzàlez, J., Hayden, T., Katsuki, K., Olney, M. P., Pekar, S. F., Shrivastava, P. K., van de Flierdt, T., Williams, T., and Yamane, M.: Chronostratigraphic framework for the IODP Expedition 318 cores from the Wilkes Land Margin: Constraints for paleoceanographic reconstruction, Paleoceanography, 27, 1-19, doi:10.1029/2012PA002308, 2012.

Truswell, E. M. and Macphail, M. K.: Polar forests on the edge of extinction: what does the fossil spore and pollen evidence from East Antarctica say?, Aust. Syst. Bot., 22, 57-106, 2009.

Van Gijzel, P.: Palynology and Fluorescence microscopy, Rev. Palaeobot. Palyno., 2, 49-79, 1967.

Van Gijzel, P.: Review of the UV-fluorescence microphotometry of fresh and fossil exine and exosporia, in: Sporopollenin, edited by: Brookes, J., Grant, P. R., Muir, M., Van Gijzel, P., and Shaw, G., Academic Press, London, New York, 659-685, 1971.

Warny, S., Kymes, M., Askin, R. A., Krajewski, K. P., and Bart, P. J.: Remnants of Antarctic vegetation on King George Island during the early Miocene Melville Glaciation, Palynology, 40, 66-82, doi:10.1080/01916122.2014.999954, 2016.

Waterhouse, H. K.: Palynological fluorescene in hinterland reconstruction of a cyclic shallowing-up sequence, Pliocene, Papua New Guinea, Palaeogeogr. Palaeocl., 139, 59-82, doi:10.1016/S0031-0182(97)00118-1, 1998.

Wilson, D. S., Jamieson, S. S., Barrett, P. J., Leitchenkov, G., Gohl, K., and Larter, R. D.: Antarctic topography at the Eocene-Oligocene boundary, Palaeogeogr. Palaeocl., 335, 24 34, doi:10.1016/j.palaeo.2011.05.028, 2012.

Yeloff, D. and Hunt, C.: Fluorescence microscopy of pollen and spores: a tool for investigating environmental change, Rev. Palaeobot. Palyno., 133, 203-219, doi:10.1016/j.revpalbo.2004.10.002, 2005. 